International Journal of Current Advanced Research

ISSN: O: 2319-6475, ISSN: P: 2319 - 6505, Impact Factor: SJIF: 5.995

Available Online at www.journalijcar.org

Volume 6; Issue 5; May 2017; Page No. 3694-3705

DOI: http://dx.doi.org/10.24327/ijcar.2017.3705.0349

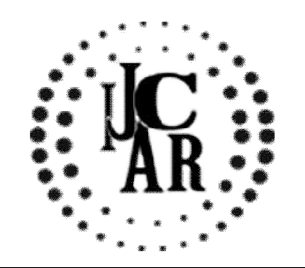

Research Article

\title{
ENGLISH VOWEL PHONEMIC AWARENESS OF JRU BASIC EDUCATION HONOR STUDENTS AND SELECTED TEACHERS
}

\author{
Rommel B. de la Cruz
}

Jose Rizal University, Philippines A.T. Apt. Unit C Reyes St., Mandaluyong, Philippines

\begin{tabular}{l}
\hline A R T I C L E I N F O \\
\hline Article History: \\
Received $21^{\text {st }}$ February, 2017 \\
Received in revised form $2^{\text {nd }}$ March, 2017 \\
Accepted $15^{\text {th }}$ April, 2017 \\
Published online $28^{\text {th }}$ May, 2017 \\
\hline
\end{tabular}

Key words:

Phonemic awareness, Speech Learning Model (SLM), ESL, fluency, and Philippine English \begin{abstract}
A B S T R A C T
Purpose: This research specifically investigates the level of phonemic awareness on English vowels of the JRU basic education honor students in the activities of reading, listening, and speaking. It also examines how their English vowel phonemic awareness in reading is related to certain profile variables.
\end{abstract}

Method: The study adapted descriptive survey approach since it intended to describe the phenomenon of interest. For this purpose, it developed a research instrument, Vowel Phoneme Sample Test (VPST). VPST was administered in the summer of 2013 to the target participants.

Results: About $63 \%$ of participants from students got scores of $26-30$; around $66 \%$ of them from Faculty obtained the same scores. On Pearson correlations of the English vowel phonemic awareness and the academic level of JRU basic education honor students and selected Faculty, reading obtained 0.398, speaking 0.206, and listening 0.355 .

Conclusions: More than the majority of participants from JRU basic education teachers and students manifested phonemic awareness. They could speak English with vowel phonemes a bit similar to that of the native speaker. The language activities are significant of reading and speaking, whereas the phonemic awareness in listening as related to academic level is significant. This means the many of the JRU honor students could recognize and distinguish vowel phonemes as they go higher in academic level.

Copyright $₫ 2017$ Rommel B. de la Cruz.This is an open access article distributed under the Creative Commons Attribution License, which permits unrestricted use, distribution, and reproduction in any medium, provided the original work is properly cited.

\section{INTRODUCTION}

Phonemic awareness is essential in literacy. In learning to speak ESL, children can only be successful if they have good phonemic awareness. Research has established its importance, indicating it as a requisite for developing reading skills (Anderson, Hiebert, Scott, \& Wilkerson 1985; Adams 1990; Snow, Burns, \& Griffin 1998 as cited in Tankersley, 2003). Mckenna and Walpole (2007) reported a governmentsponsored research aimed at investigating phonemic awareness. The U.S. Congress organized the National reading Panel (NRP) "to summarize research in the areas of phonemic awareness, phonics, decoding, fluency, vocabulary, comprehension, and teacher education." The panel was formed principally to improve the instruction on literacy.

The competence of a language user in spoken English would only be partly revealed in the speech sounds he produces and in the minute difference of these sounds he can distinguish. The native speakers, being exposed to these speech sounds at

*Corresponding author: Rommel B. de la Cruz

Jose Rizal University, Philippines A.T. Apt. Unit C Reyes St., Mandaluyong, Philippines an early age, have acquired this competence. The adult native language speakers pronounce slowly vowel and consonant phonemes, a language style that promotes language acquisition. Factors such as repetition by the adult speakers and redundancy of the context facilitate the acquisition of English. The formal education these young native speakers receive further develops this competence.

Not growing in an environment where English is spoken, ESL speakers experience anxiety, and this feeling is more apparent when they are learning English in a classroom setting. Teachers are not spared from the uncomfortableness inherent in speaking and writing in ESL. Bautista (2001), after underscoring the variety of English (American English) taught in the country, critically remarked that both the "students and even faculty members know that their mastery of English is not complete and that they sometimes commit mistakes in English pronunciation." This condition of uneasiness Filipinos struggle with in their pursuit to attain fluency in speaking English might have precipitated the evolution of the local variety of English, the Philippine English (PE). This local variety of English has been defined differently. 
Whereas Andrew Gonzales thought of it, according to The Oxford Companion to the English Language, as "English long spoken in the Philippines," Teodoro Llamson viewed it as "the type of English which educated Filipinos speak, and is acceptable in educated Filipino circles" (Maminta 2001). Whether they end up speaking Philippine English or that of its prestigious variety is immaterial. The important issue is, they can be assured through an effective instruction in speech that "they speak a legitimate and robust variety of English called Philippine English" (Bautista 2001).

The teaching and learning of English should transmit the "model" variety of English, regardless whether it is Standard American English (SAE) or Philippine English (PE). Model variety suggests it is used in education and can be used in higher cultural activities. It has to be the spoken form, though it can also transmit thoughts and information in its written form. The many decades of experience of teaching English through audiolingualism, reading approach, and translation approach have proven that $\mathrm{PE}$ or SAE has to adapt the concepts, techniques, and other strategies the research of language study and language teaching have developed. This belief was echoed by a prominent scholar of language, who said that people "must realize that all things being equal, the knowledge of the basic principles of linguistics, and their application to language teaching, will make a difference on one's classroom performance and effectiveness (Llamzon 1971). People who speak English as native or non-native speakers strive to approximate what they think as the model exemplification of the English of the high-heeled and the intellectuals. This practice of approximation has been largely introduced during the period of formal education. Even teachers though find this practice of approximation difficult, because they themselves are not familiar with certain English phonemes, nor they know the distinction among them, both receptively and productively, especially when the segments are realized at the phonetic level. Thus, it begs the question: Who can effectively teach the Filipino children how to speak English? Teachers, mass media, parents, or model speakers: These answers beg more explanations that raise more questions.

\section{Statement of the Problem}

Presuming that the pronunciation of these SAE vowel phonemes can be facilitated by following IPA phonetic symbols and procedures or those of others developed by language study as a science, how much are the JRU basic education honor students and selected teachers aware of these English vowel phonemes? Awareness suggests they have automatized the pronunciation of these phonemes as well as their representation in written form. The underlying attitudes encourage the development of this automatization. Thus, this research specifically intends to address the following questions:

What is the level of phonemic awareness on English vowels of the JRU basic education honor students in the following activities

$$
\begin{array}{ll}
1.1 & \text { Reading } \\
1.2 & \text { Listening } \\
1.3 & \text { Speaking }
\end{array}
$$

Is the English vowel phonemic awareness of the participants in reading related to the following

1.4 Academic Performance

1.5 Gender

1.6 Academic Level

1.7 Favorite Subject (For teacher subject assigned to teach)

1.8 Language Spoken Parents

2.5.1 Both Speaking Tagalog-

2.5.2 The Other Speaking Local Non-Tagalog Language

2.5.3 Both Speaking Non-Tagalog Languages -

2.5.4 The Other Speaking Foreign Language (Including English) -

\section{Review of Literature}

The function of phonemic awareness in literacy, not only in speech and language acquisition as well as language learning, is incomparably invaluable. Deano (2006) agreed with those researchers who said that "phonemic awareness is the best predictor of success in the reading cognitive process," defining it as the "understanding about the smallest units of sounds, the phonemes, that make of the speech stream." In speech, when phonemic awareness function is not actively sought and harnessed, it can lead to less fluency; in reading, it can retard the progress in reading as other skills like word recognition, vocabulary growth, and discourse familiarity will not be acquired by the individuals.

In line with this research, which related speech to certain personal variables, Diaz (1995) examined the "relationships among the use of oral communicative strategies (OCS) by second language learners and selected learner variables, namely age of cleaners, their home language, the number of months each were exposed to the English language ." It reveals among others that "beginner ESL learners exhibited the most use of OCS followed by the Intermediate learners; advanced learners used the fewest OCS; all three groups of learners used more OCS in time I than is time II."

Roy (2008) opposed what many theories propose about the age as being crucial factor in acquiring a native-like proficiency. He agreed though on studies he reviewed that "younger is better in acquiring the phonology of a L2" and that the cut-off age for the ability to acquire native-like pronunciation is age 6. Dalton and Seidlhofer (1994), citing the affective theory, believed that age affects the learning spoken L2, whether it is going to sound like that of L1 speakers or heavily influenced by the native language. They commented that "while no age stands out as optimal for all aspects of foreign language learning, it has been established that due to certain psycho-sociological factors, our resistance to modifying our pronunciation increases as we get older: our boundaries get established with age, our 'language ego' becomes less flexible." Barone (2006) reported about very young elementary graders, "regardless of home language, had not acquired academic language." They could not sustain a conversation. Though she admitted that phonemic awareness as a perquisite to successful reading, she concluded in her study it was not predictive. She remarked "the explicit focus on phonics and decoding in first grade was a necessary step in learning to read and write." However, she had gathered evidence that "teachers at all grade levels can make a 
difference in student achievement in reading."The development of speech is intertwined in the acquisition of phonemic awareness. Phonemes have to be recognized acoustically, then processed cognitively for memory imprinting and automatized oral production. Tankerly (2003) observed that "some children can be delayed in phonemic awareness skills is due to poor or slowly developing oral language skills." She added "sometimes children are not able to enunciate all of the phonemes they may be exposed in oral language."Gender is commonly held as a factor in stereotyping children as language users. Nonetheless, Edwards (2008) contradicted the observation that gender affects pronunciation. He cited studies which do "not show gender to be a strong predictor of pronunciation accuracy." Girls are believed to think more before they speak, suggesting a longer language processing, and are said to acquire language in earlier age. They comply with conversation rules and try hard to imitate adult speech.

The higher year level children have gone, the more they are expected to display a better language competence. Jones and McLachlan (2009) suggested that higher academic level is relevant with language acquisition and learning. They remarked that "certainly, KS2 pupils, particularly those in upper KS2, are becoming increasingly sophisticated in their use of English particularly in terms of how they express themselves verbally, in what they read, and in what they are required to write." They proposed that "the acquisition of a new language in a classroom works best when all key language competencies - listening, speaking, reading, and writing - are carefully blended to provide a whole language experience."Aligned to this, examining Filipino English and Taglish, Thompson (2003) noted that Filipinos thought that "if their English is good enough to graduate from high school, it should be good enough to enter the university without further testing." He cited a Filipino linguistic scholar who revealed that many local teachers speak a mixture of English and Tagalog to their children.

The huge amount of investment usually in language education is justified by its essential role in academic performance. Research usually agrees with this. Combista (1995) revealed that there is a transfer of Cognitive Academic Learning Proficiency skills from L1 (first language) to L2 (second language), and CALP in L1 can affect academic successor in L2. She added that "learners who are proficient in the cognitive academic aspects of their L1 can perform better in academic subjects taught in L2 than those who are not, provided they are also proficient in their L2." She seemed to agree with the important premise of this research that bilingual learners must attain a minimum level of competence in "both their L1 and L2 in order to benefit from it academically." Her conclusion is also aligned with the most prevalent belief that certain proficiency in L1 and L2 must be attained for CALP skills to be transferred from these languages and would thus result in learning. This research fulfills the first step toward progressing to language proficiency. Academic success somehow is affected by the development taking place in speech. Ramirez (1985) remarked that "other researchers have noted how the level of competence in L1 and L2 attained by bilinguals affects cognitive development and academic performance." Majority of the Filipino children are bilingual with English as the other language they are exposed on. It is a language that is preferred in education, entertainment, communication, and mass media. Thus, it is inevitable for these learners to acquire and learn English. Since a large part of classroom interaction and activity is in English, competence in English is observed to affect the way they think and learn. Good pronunciation is the production of vowel and consonant sounds accurately with the aim of being understood satisfactorily (Sheeler and Markley 1991). The privileging of speech over competence in grammar can oftentimes redound to discrimination of non-native speakers of English, though many of them are educationally qualified to teach English (Goodwin 2005). Asian countries, including South Korea and Taiwan, would rather hire native speakers of English as teachers though lacking the appropriate qualifications. Their governments connect competence in English with fluency. David (2010) defined fluency as having a "'native-like' speech, having a high overall degree of proficiency, or having a "good command" of a language."

It is arguable whether native speakers, educated or noneducated, speak the 'ideal' spoken English. In this line, Verderber et al. (2009) commented about the fluency of speakers of English like him who "suffer from minor articulation and pronunciation problems."Sounding off close to this study as he also scrutinized the Filipino English speech sounds, Peredo-Sarile (1986) investigated "the comprehensibility and acceptability of phonological varieties of Filipino-English as used in academic lectures." She found out "that the American and Filipino respondents differed significantly in their attitudinal, acceptability, and comprehensibility evaluations of the four phonological varieties of Filipino-English." The study disclosed a significant positive correlation between comprehensibility and acceptability. The preference for the native prestigious variety of English is ubiquitous. Kobayashi (2008) observed that Taiwanese "seem to consider that the success of learning English means mastery of the "American Standard." He reported that though Taiwanese who studied in the Philippines found the quality of teaching English satisfactory many of them still preferred the teaching be done by L1 speakers. They relished being able to have contact with the $\mathrm{L} 1$ varieties.

Kunschak and Fang (2008), however, disputed that "more students still see the significance of 'intelligibility' as a 'norm' of their pronunciation level." They held that even teachers promoted intelligibility. They were convinced that "the native-like model is no longer the ultimate goal of learning and using English because more and more bilingual or multilingual speakers use English in different ways."

Garcia-Aranas (1988) determined the characteristics of the 'educated' Philippine English. The participants were English and Mathematics teachers on the tertiary level of education. This study continued the linguistic enterprise aimed at exploring the existence of the Philippine variety of English started by Andrew Gonzales and Nelia Casambre. It was reported that both groups of teachers used similar features though they ranked them differently. Omission, peculiar order, and splits were the common syntactic features between the two. The conclusion was "that both English and Mathematics teachers used PVE with the lexico-semantic and syntactic features." Being aware of the SAE phonemes makes it possible to develop fluency and intelligibility whether in a variety of English spoken in the classroom. A teacher who is familiar with SAE and other varieties of English may be able to point out the difference among varieties and model the 
target variety. On this, De los Reyes-Videheecharoen (2000) attempted to "describe and compare classroom verbal and non-verbal interactions of native English teachers and nonnative English teachers with Thai learners to discover whether there are differences in their patterns of interactions." The two groups of teacher participants were similar in their openings and follow-up moves. Only the native English group of teachers was found to have accommodated the speech styles of their learners through the strategies of pronunciation and code/language switching. Both groups of teachers employed the same number and varied ways of rendering their linguistic input comprehensible using phonological, lexical, and syntactic strategies.

The motivation and purpose of acquiring and learning a language, which is an aspect of this research, cannot be overlooked. Jareta-Gonzales (1990) investigated how the measures of socio-psychological distance and attitudinal motivations can result in the difference of "the social and personality characteristics of the Filipino bilingual immigrants who required the American English norms" and of "those Filipino bilingual immigrants who persisted in the use of Filipino English formulaic expressions." She looked into the destabilizing effect on the Philippine English of the acquisition of ESL by describing the "comprehensibility and acceptability of frequently used Filipino-English formulaic expressions."'In the same vein, Jaffrey (1984) analyzed the "language use and language attitudes in Quetta City, Pakistan, today." It recognizes the rational foundations of national language policy: 1) a survey of language in use, 2) a language attitude survey, and 3) people's views concerning language in use and the country's existing language policy. Among the significant findings are as follows: as the language in school, parents preferred Urdu as medium of instructions for Kindergarten and class four; English and Arabic to be introduced as subjects; from class five to college and university, Urdu, English, and Arabic were the preferred languages. The notable finding though reports "the children having difficulty in all the four skills in English with speaking being the most difficult."

To formulate their communicative syllabus, Lagare (1998) investigated the communicative needs of the first year BSIE students of the University of Southeastern Philippines. The subjects were instructors, students, BSIE graduates, and then employers. She found out that the first year BSIE students had to cultivate communication skills for their Industrial Education academic performance. Aside from relating phonemic awareness with academic level and performance, the review of literature done here posits the following points: that Oral Communicative Strategies classify learners of English with age which seems to suggest the latter affect learning English; that phonemic awareness is instrumental in learning ESL with the role of the variable of gender accentuating it; and that it connects fluency with the development of ESL and the emergence of Philippine English.

\section{Theoretical Framework}

English vowels are the nucleus of the production of words. They carry the stress and give meaningful shape to the pitch. They constitute the range of sounds where the rising and falling down of tone, the intonation, flows. Ogden (2009) illustrated the essential role of vowels in English phonetics by citing all-vowel words such as eye and awe. Vowels, being syllabic, do not adjust with the adjacent consonants. It is the other way around. The IPA has established a set of reference vowels called cardinal vowels (CVs). They have predetermined phonetic values that can be used to describe other values.

James E. Flege's Speech Learning Model (SLM) proposes "that difficulties in perception of non-native vowel contrasts are a significant part of the problems many L2 learners have in mastering the L2 phonology" (Bohn and Munro 2007). SLM which informs this research asserts that semblance in phonetic features or values between L1 and L2 phonemes results in difficulty in phonemic recognition and distinction. The hearing and processing of L 2 phonemes is affected by L1 developed and shaped perceptual mechanisms which identify the L2 phonemes as exemplars of L1 phonemes. This model posits that two L1 phonemes being assimilated into a particular L1 phoneme would make the contrast of two L2 phonemes difficult.Flege (2011) explains the cause of this perceptual interference of L1 to L2:

This is consistent with the classic view of perceptual development which suggests that children become increasingly reliant sensory information as they develop cognitively and learn to ignore attributes of sensory stimuli that are irrelevant to classification. Learning to focus attention on just those aspects of sounds needed for phonemic contrasts also seems to characterize the perception of L2 sounds by adults.

SLM is related with Contrastive Analysis Hypothesis (CAH), which portrays L2 acquisition as the formation of habits (Gut 2009). CAH is based on the observation that L1 and L2 share a number of behavioral features. Filipinos speak English as ESL. They are introduced to English only in the formal education. They speak a local vernacular at home. If this is not Tagalog, which is used by many in Manila, it could be another local languages, such as Ilocano, Bicolano, Hiligaynon, Bisaya among others. In this linguistic milieu, SLM depicts the acquisition and production of ESL as filtered through L1. Figure 1 illustrates this. The phonemic awareness of the participants was examined here in these three literacy activities - reading, speaking, and listening. This study adapted both the articulatory and auditory criteria

\section{(Collins and Leidin 2003). It focused on the following parameters}
1. Tongue shape
2. Lip shape
3. Whether 1 and 2 are held constant or undergo change
4. Position of the soft palate
5. Duration
6. Larynx setting variation

The tongue shape is related to the lip shape. They are spread and flat for vowels classified as moderately closed or closed $(/ \mathrm{i} /, / \mathrm{I} /$, and $/ \mathcal{E} /$ ). The lips are pursed, and the tongue curled for moderately opened or opened vowels $(/ \mathrm{u} /, / \mathrm{v} /$, and $/ \mathrm{o} /)$. Vowels articulated with the soft palate being pushed forward are moderately opened or opened; those pushed back are moderately closed or closed. Duration determines the difference between tense $(/ \mathrm{i} /$ and $/ \mathrm{u} /)$ and lax $(/ \mathrm{I} /$ and $/ \mathrm{\mho} /)$. A space is created for back vowels $(/ \mathrm{u} /, / \mathrm{\sigma} /, / \mathrm{o} /$, and $/ \mathrm{o} /)$ than front vowels (/i/, / I /, /E/, and /æ/). There are also the mid low 
and central vowels $(/ \mathrm{a} /, / \mathrm{\partial} /$, and $/ \Lambda /)$. The theoretical model of vowel description in this study also observes the criteria of

vowel quality (Kreidler 1997), and these are as follows

1. The raising of the tongue

2. The height of tongue raising

3. The rounding of the lips

\section{Research Method}

This study aimed to gather data about the vowel phonemes of elementary school and high school honor students and teachers of Jose Rizal University. It adapted descriptive survey approach since it intended to describe the phenomenon of interest. For this purpose, it developed a research instrument, Vowel Phoneme Sample Test (VPST). VPST was administered in the summer of 2013 to the target participants. This section presents the research instrument, procedures, and statistical treatment.

\section{Research Instrument}

This study used the Vowel Phoneme Sample Test (VPST). (Appendix A) VPST aims to gather speech data which describe the vowel phonemic inventory of a person who uses English in communication. VPST focuses only on vowel phonemes which Filipino users of English find difficult to pronounce, and these are represented in IPA as $\mathcal{E}, \boldsymbol{c}, \boldsymbol{\Lambda}, \boldsymbol{\jmath}, \mathbf{a}$, and $\boldsymbol{\partial}$. This test is done in the communication activities of reading, speaking, and listening. It is divided into two parts: the Personal Profile and the Test Proper. The profile information consists of the following: gender, highest grade in most recent English subject, year level (years of service for a teacher), favorite subject (subject usually assigned to teach for a teacher), and language other than English parents speak. For the reading activity, the participant will be shown flash cards where sentences below are written. They will be asked to read each sentence loudly. For each sentence a particular vowel phoneme will be the focus which is found into two words.

\section{The letters in boldface print represent these vowels.}

1. In the opening line of that novel, I have read "The serenity on the top of the mountain is surreal."

2. The little boy is acting up by laughing loud.

3. The idiom "Büt it does not cut ice," means it is not effective.

4. Mina thought she caught you.

5. The sergeant is in the cot.

6. She is alone in the sofa.

For the speaking activity, the sentences below are intended to be the topics of a conversation with participants of this study. The researcher should pique their interest by asking questions. Nonetheless, since the sentences contain the vowel phonemes, he should make the students repeat or pronounce them, either by telling directly or by asking lead questions.

\section{They are found in two words in each sentence}

1. The hit-and-run victim was almost dead when the driver fled.

2. Your dad is mad because you went home almost dawn of today. What will you do?

3. The flood cuts a new river. What does this mean to the farmers?
4. People are awed with the way the new player shoots (hits) the ball.

5. The army car of Datu Kiram is parked outside. How do peace-loving feel?

6. The symphony and melody are magnificent. What will make a good music?

For the listening activity, a participant will watch a video in which he will be listening to the model who carefully reads sentences (Appendix A). These sentences are in the sheet supplied to the participant. The letter or letters in boldface print in each word stand for the vowels being examined. After the sentences which are italicized are read, the un-italicized sentences will be read again before he is allowed to encircle the letter which identifies the sentence of his choice. These sentences have words with vowels being scrutinized as to whether they are known to the participant. Six of them correspond to the six italicized sentences because they share

\section{Similar vowels in boldfaced. Below are the sentences}

1. a. I beat you. b. It is in the bin. c. There is the bait. d. My bet is Php 50 . The bed is wet.

2. a. The lad runs away. b. The log sinks. c. Danger lurks. d. That's the law.

The toddler laughs funnily.

3. a. Everything is calm. b. Hold the cane. c. Cut it. d. Call later.

The primary suspect is caught.

4. a. But I'm fine. b. Bank opens at 8 o'clock. c. Get the bat. d. I bought it.

The bus arrives late.

5. a. The concert is hot. b. My pinkie hurts. c. There's the hamster. d. It's hemmed. We are happy for the outcome.

6. America grieves. b. All is lost. c. Atlas is a good reference. d. Art is his major.

He and his old man are alike in many ways.

\section{Scoring the Data}

Two criteria are followed in the scoring of the answers. The vowel which sounds very unlikely and differs on the criteria of either the raising of the tongue, the height of tongue raising, or the rounding of the lips gets from highest to lowest scores $(5,4,3,2,1)$. Below is the table of scoring:

\section{Reading}

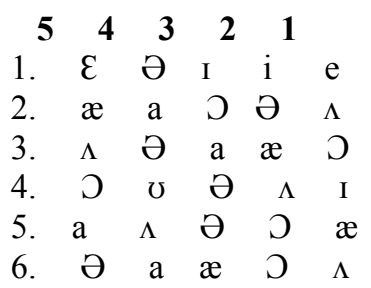

Speaking

\begin{tabular}{|c|c|c|c|c|}
\hline 5 & 4 & 3 & 2 & \\
\hline 1. $\varepsilon$ & $\partial$ & I & $\mathrm{e}$ & \\
\hline 2. æ & $\mathrm{a}$ & $\partial$ & $\varepsilon$ & \\
\hline$\Lambda$ & $\mathrm{a}$ & $æ$ & T & \\
\hline O & 0 & a & & \\
\hline $\mathrm{a}$ & $æ$ & $\partial$ & & \\
\hline$\partial$ & & & & \\
\hline
\end{tabular}




\section{Listening}

$\begin{array}{cccccc} & \mathbf{5} & \mathbf{4} & \mathbf{3} & \mathbf{2} & \mathbf{1} \\ \text { 1. } & \mathrm{d} & \mathrm{c} & \mathrm{a} & \mathrm{b} & \\ \text { 2. } & \mathrm{a} & \mathrm{b} & \mathrm{c} & \mathrm{d} & \\ \text { 3. } & \mathrm{d} & \mathrm{c} & \mathrm{a} & \mathrm{b} & \\ \text { 4. } & \mathrm{a} & \mathrm{b} & \mathrm{d} & \mathrm{c} & \\ \text { 5. } & \mathrm{c} & \mathrm{b} & \mathrm{a} & \mathrm{d} & \\ \text { 6. } & \mathrm{a} & \mathrm{d} & \mathrm{c} & \mathrm{b} & \end{array}$

The research paradigm below illustrates the variables and the process involved in the completion of this study. The input refers to the profile of the participants, and the process stands for the administration of the Vowel Phoneme Sample Test (VPST). The application of the VPST results in the examination of the ESL vowel phoneme awareness of JRU basic education honor students and selected Faculty. The output of the study is a training which aims to enhance the vowel phoneme awareness of JRU basic education pupils and students as well as Faculty.

\section{Statistical Treatment}

The statistical tools that were used in this study are as follows

\section{Range of values}

\begin{tabular}{|c|c|c|}
\hline \multirow{2}{*}{\multicolumn{3}{|c|}{$\begin{array}{l}\mathbf{1 . 0} \\
\text { Correlation }\end{array}$}} \\
\hline & & \\
\hline $0.80-0.99=$ & Very High & (Positive/negative) \\
\hline Correlation & & \\
\hline $0.60-0.79=$ Hig & h (Positive/negati & tive \\
\hline $0.40-0.59=$ & Moderate & (Positiv \\
\hline Correlation & & \\
\hline $\begin{array}{l}\mathbf{0 . 2 0}-\mathbf{0 . 3 9}= \\
\text { Correlation }\end{array}$ & Weak or Low & (Positive/negative) \\
\hline $0.00-0.19=$ & Very & or \\
\hline
\end{tabular}

\section{Chi-square with degrees of freedom and P-value}

The Chi-square statistic is the sum of the squares of the differences of observed and expected frequency divided by the expected frequency for every cell:If the calculated P-value is less than 0.05 , then there is a statistically significant relationship between the two classifications. The Contingency Coefficient is a measure of the degree of relationship, association of dependence of the classifications in the frequency table. The coefficient is calculated as follows ( $\mathbf{n}$ is the total number of cases in the table):

The larger the value of this coefficient, the greater the degree of association. The maximum value of the coefficient, which is never greater than 1 , is determined by the number of rows and columns in the table. Percentage and frequency are used throughout the analysis of the data. Below are the levels and descriptive grades employed:

\section{Analysis, Interpretation, and Discussion}

Table 1 reveals that $79 \%$ of participants obtained scores of 41-50 in their phonemic awareness in reading. At least $13 \%$ of them got scores of 31-40, and only eight percent had scores of 51-60. The results suggest that almost all of the honor basic education students had very satisfactory phonemic awareness. They could distinguish English vowels many Filipinos find difficult to pronounce when reading. The JRU honor students expected to be fond of reading. Being good readers, they can demonstrate phonemic awareness. Deano (2006) supports the observation on the relationship between reading and phonemic when he pointed out that "phonemic awareness is the best predictor of success in the reading cognitive process." He defined it as the "understanding about the smallest units of sounds, the phonemes, that make of the speech stream."

Table 1 Phonemic Awareness Performance in Reading

\begin{tabular}{|c|c|c|c|c|c|}
\hline \multirow{3}{*}{ Score } & \multicolumn{4}{|c|}{ No of Participants (f) } & \multirow{3}{*}{ Verbal Interpretation } \\
\hline & \multicolumn{2}{|c|}{ Student } & \multicolumn{2}{|c|}{ Teacher } & \\
\hline & $\mathbf{F}$ & Percent & $\mathbf{F}$ & Percent & \\
\hline $51-60$ & 4 & 8 & 3 & 33.33 & $\begin{array}{c}\text { Excellent Phonemic Awareness } \\
\text { Level }\end{array}$ \\
\hline $41-50$ & 38 & 79 & 3 & 33.33 & $\begin{array}{c}\text { Very Satisfactory Phonemic } \\
\text { Awareness Level }\end{array}$ \\
\hline $31-40$ & 6 & 13 & 3 & 33.33 & $\begin{array}{l}\text { Satisfactory Phonemic } \\
\text { Awareness Level }\end{array}$ \\
\hline $21-30$ & & & & & $\begin{array}{c}\text { Fair Phonemic Awareness } \\
\text { level }\end{array}$ \\
\hline $11-20$ & & & & & $\begin{array}{c}\text { Poor Phonemic Awareness } \\
\text { Level }\end{array}$ \\
\hline Total & 48 & 100 & 9 & 99.99 & \\
\hline Student: & & $\begin{array}{l}\text { in }=44 \text {. } \\
\text { cher: }\end{array}$ & Mea & 45 & $\begin{array}{l}\text { Standard Deviation }=3.74 \\
\text { Standard Deviation }=8\end{array}$ \\
\hline
\end{tabular}

With regard to phonemic awareness in listening, which is shown in Table 2, 96\% of participants from students got scores of $41-50$, whereas $66.67 \%$ from teachers. These data indicate that almost all of JRU basic education students and a bit higher than majority of JRU basic education teachers demonstrated satisfactory phonemic awareness. They could recognize the difference among problematic English sounds.

Table 2 Phonemic Awareness Performance in Listening

\begin{tabular}{|c|c|c|c|c|c|}
\hline \multirow{3}{*}{ Score } & \multicolumn{4}{|c|}{ No of Participants } & \multirow{3}{*}{ Verbal Interpretation } \\
\hline & \multicolumn{2}{|c|}{ Student } & \multicolumn{2}{|c|}{ Teacher } & \\
\hline & $\mathbf{F}$ & Percent & $\mathbf{F}$ & Percent & \\
\hline $51-60$ & 2 & 4 & 3 & 33.33 & $\begin{array}{c}\text { Excellent Phonemic } \\
\text { Awareness Level }\end{array}$ \\
\hline $41-50$ & 46 & 96 & 6 & 66.67 & $\begin{array}{c}\text { Very Satisfactory Phonemic } \\
\text { Awareness Level }\end{array}$ \\
\hline $31-40$ & & & & & $\begin{array}{c}\text { Satisfactory Phonemic } \\
\text { Awareness Level }\end{array}$ \\
\hline $21-30$ & & & & & $\begin{array}{c}\text { Fair Phonemic Awareness } \\
\text { level }\end{array}$ \\
\hline $11-20$ & & & & & $\begin{array}{l}\text { Poor Phonemic Awareness } \\
\text { Level }\end{array}$ \\
\hline Total & 48 & 100 & 9 & 100 & \\
\hline $\begin{array}{l}\text { Student: } \\
\text { Teacher: }\end{array}$ & $\begin{array}{l}\text { Mean } \\
\text { Mean }\end{array}$ & & & $\begin{array}{l}\text { Standar } \\
\text { Standar }\end{array}$ & $\begin{array}{l}\text { eviation }=2.93 \\
\text { eviation }=2\end{array}$ \\
\hline
\end{tabular}

Based on the data in Table 3,63\% of participants from students got scores of 26-30; around $66 \%$ of them from Faculty obtained the same scores. More than the majority of participants from JRU basic education teachers and students manifested phonemic awareness. They could speak English with vowel phonemes a bit similar to that of the native speaker. Pedro-Serile (1986) reported about the higher evaluation of Filipinos for urban-centered Philippine English. JRU honor students want to speak this variety of English, which may be not that far to Standard American English (SAE). This prestigious variety is promoted well to the Filipinos through media, entertainment, business, and education. With communication reconstituted by mobile telephone technology and reappropriated by the Net universe, SAE might have been restructuring the Philippine English phonology. Young ESL speakers are massively exposed to this variety that it is not an overstatement it has imprinted on their use of English. On Pearson correlations of the English 
Table 3 Phonemic Awareness Performance in Speaking

\begin{tabular}{|c|c|c|c|c|c|}
\hline \multirow{3}{*}{ Score } & \multicolumn{4}{|c|}{ No of Participants (f) } & \multirow[b]{3}{*}{ Verbal Interpretation } \\
\hline & \multicolumn{2}{|c|}{ Student } & \multicolumn{2}{|c|}{ Teacher } & \\
\hline & $\mathbf{F}$ & Percent & $\mathbf{F}$ & Percent & \\
\hline $26-30$ & 30 & 63 & 6 & 66.67 & $\begin{array}{c}\text { Excellent Phonemic } \\
\text { Awareness Level } \\
\text { Very Satisfactory }\end{array}$ \\
\hline $21-25$ & 16 & 33 & 3 & 33.33 & $\begin{array}{c}\text { Phonemic Awareness } \\
\text { Level }\end{array}$ \\
\hline $16-20$ & 2 & 4.2 & & & $\begin{array}{c}\text { Satisfactory Phonemic } \\
\text { Awareness Level }\end{array}$ \\
\hline $11-15$ & & & & & $\begin{array}{l}\text { Fair Phonemic } \\
\text { Awareness level }\end{array}$ \\
\hline $0-10$ & & & & & $\begin{array}{l}\text { Poor Phonemic } \\
\text { Awareness Level }\end{array}$ \\
\hline Total & 48 & 100 & 9 & 100 & \\
\hline $\begin{array}{l}\text { tudent: } \\
\text { Teacher: }\end{array}$ & $\begin{array}{l}\text { Mean } \\
\text { Mean }\end{array}$ & $\begin{array}{l}=26.3 \\
=26.7\end{array}$ & & $\begin{array}{l}\text { Standard D } \\
\text { tandard De }\end{array}$ & $\begin{array}{l}\text { viation }=3.13 \\
\text { viation }=3.1\end{array}$ \\
\hline
\end{tabular}

vowel phonemic awareness and the academic performance of JRU basic education honor students and selected Faculty, reading obtained -0.218 , speaking -0.027 , and listening -.185. These are all not significant as shown in Table 4. The phonemic awareness of participants in reading, speaking, and listening is not related to their academic performance. This refutes the conclusion that "other researchers have noted how the level of competence in L1 and L2 attained by bilinguals affects cognitive development and academic performance" (Ramirez 1985).
As revealed Table 5, on Pearson correlations of the English vowel phonemic awareness and the gender of JRU basic education honor students and selected Faculty, reading obtained -0.250 , speaking -0.070 , and listening -0.194 . The phonemic awareness in the speech components of speaking and listening as related to gender is negative very low correlation; it is not significant. The phonemic awareness in reading as related to gender is significant. This suggests that being male or female seemed to affect how JRU honor students, and selected Faculty recognize and distinguish English vowels. These findings are in harmony with the conclusion that gender is a factor in the development of phonemic awareness (Hansen Edwards 2008). Girls are thought to be a bit careful in their speech, and they pattern it to that of adults, especially celebrities they admire.

Table 6 shows that on Pearson correlations of the English vowel phonemic awareness and the academic level of JRU basic education honor students and selected Faculty, reading obtained 0.398 , speaking 0.206 , and listening 0.355 . The phonemic awareness in the speech components of reading and listening as related to gender is low correlation. The language activities are significant of reading and speaking, whereas the phonemic awareness in listening as related to academic level is significant. This means the many of the JRU honor students could recognize and distinguish vowel phonemes as they go higher in academic level.

Table 4 Correlation of English Vowel Phonemic Awarenessand Academic Performance of the Participants

\begin{tabular}{ccccccc}
\hline & \multicolumn{5}{c}{ Academic Performance } & \\
\cline { 2 - 5 } Variables & $\mathbf{N}$ & $\begin{array}{c}\text { Sig. } \\
\text { (1-tailed) }\end{array}$ & Pearson Correlation & Interpretation & Decision & Interpretation \\
\hline $\begin{array}{c}\text { English Vowel Phonemic } \\
\text { Awareness in Reading }\end{array}$ & 43 & 0.080 & -0.218 & Negative Low Correlation & Accept Ho & Not Significant \\
$\begin{array}{c}\text { English Vowel Phonemic } \\
\text { Awareness in Speaking }\end{array}$ & 43 & 0.433 & -0.027 & Negative Very Low Correlation & Accept Ho & Not Significant \\
$\begin{array}{c}\text { English Vowel Phonemic } \\
\text { Awareness in Listening }\end{array}$ & 43 & 0.117 & -.185 & Negative Very Low Correlation & Accept Ho & Not Significant \\
\hline
\end{tabular}

Table 5 Correlation of English Vowel Phonemic Awareness andGender of the Participants

\begin{tabular}{|c|c|c|c|c|c|c|}
\hline \multirow[b]{2}{*}{ Variables } & \multicolumn{4}{|c|}{ Gender } & \multirow[b]{2}{*}{ Decision } & \multirow[b]{2}{*}{ Interpretation } \\
\hline & $\mathbf{N}$ & Sig. (1-tailed) & $\begin{array}{c}\text { Pearson } \\
\text { Correlation }\end{array}$ & Interpretation & & \\
\hline $\begin{array}{c}\text { English Vowel Phonemic Awareness } \\
\text { in Reading }\end{array}$ & 48 & 0.043 & -0.250 & Negative Low Correlation & Reject Ho & Significant \\
\hline $\begin{array}{c}\text { English Vowel Phonemic Awareness } \\
\text { in Speaking }\end{array}$ & 48 & 0.317 & -0.070 & Negative Very Low Correlation & Accept Ho & Not Significant \\
\hline $\begin{array}{c}\text { English Vowel Phonemic Awareness } \\
\text { in Listening }\end{array}$ & 48 & 0.117 & -0.194 & Negative Very Low Correlation & Accept Ho & Not Significant \\
\hline
\end{tabular}

Table 6 Correlation of English Vowel Phonemic Awareness and Academic Level of the Participants

\begin{tabular}{|c|c|c|c|c|c|c|}
\hline \multirow[b]{2}{*}{ Variables } & \multicolumn{4}{|c|}{ Academic Level } & \multirow[b]{2}{*}{ Decision } & \multirow[b]{2}{*}{ Interpretation } \\
\hline & $\mathbf{N}$ & Sig. (1-tailed) & $\begin{array}{c}\text { Pearson } \\
\text { Correlation }\end{array}$ & Interpretation & & \\
\hline $\begin{array}{l}\text { English Vowel Phonemic } \\
\text { Awareness in Reading }\end{array}$ & 48 & 0.003 & 0.398 & Positve Low Correlation & Reject Ho & Significant \\
\hline $\begin{array}{l}\text { English Vowel Phonemic } \\
\text { Awareness in Speaking }\end{array}$ & 48 & 0.080 & 0.206 & Positive Low Correlation & Accept Ho & Not Significant \\
\hline $\begin{array}{l}\text { English Vowel Phonemic } \\
\text { Awareness in Listening }\end{array}$ & 43 & 0.007 & 0.355 & Positive Low Correlation & Reject Ho & Significant \\
\hline
\end{tabular}


Table 7 Male-Female Comparison of Vowel Segments of the Participants in Vowel Phonemic Awareness in Reading

\begin{tabular}{|c|c|c|c|c|c|c|c|c|c|c|c|c|c|}
\hline $\mathbf{F}$ & $\bar{\varepsilon}$ & $\mathfrak{x}$ & $\Lambda$ & o & $\Lambda$ & $\partial$ & $\mathbf{M}$ & $\bar{\varepsilon}$ & $F$ & $\Lambda$ & ग & $\Lambda$ & כ \\
\hline 1.ES & $\mathrm{I} / \partial$ & $\mathrm{a} / æ$ & $\mathrm{a} / \mathrm{a}$ & $\Lambda / \Lambda$ & $\mathrm{a} / \Lambda$ & $\mathrm{a} / \mathrm{a}$ & 1. ES & $\mathrm{I} / \mathcal{E}$ & $\mathrm{a} / \mathrm{s}$ & $\Lambda / \mathrm{a}$ & $\Lambda / \Lambda$ & $\varepsilon / a$ & $\mathrm{a} / \mathrm{a}$ \\
\hline 2.ES & $\varepsilon / \partial$ & $\mathrm{a} / \mathrm{\jmath}$ & ə/a & $\Lambda / \Lambda$ & $\partial / \Lambda$ & $\mathrm{a} / \mathrm{a}$ & 2. ES & $\varepsilon / \mathcal{E}$ & $a / \partial$ & $\mathrm{a} / \partial$ & $\Lambda / \Lambda$ & $\varepsilon / a$ & $\mathrm{a} / \mathrm{\partial}$ \\
\hline 3.ES & $\mathrm{I} / \mathcal{E}$ & $\mathrm{a} / \mathrm{a}$ & כ/ & $\Lambda / \Lambda$ & $\varepsilon / \mathcal{E}$ & $\mathrm{a} / \mathrm{a}$ & 3. ES & $\varepsilon / \mathcal{\varepsilon}$ & $\mathrm{a} / \mathfrak{x}$ & $\mathrm{a} / \mathrm{a}$ & $0 / \Lambda$ & $\partial / \Lambda$ & $\mathrm{a} / \mathrm{a}$ \\
\hline 4. ES & $\varepsilon / \mathcal{E}$ & $\mathrm{a} / \mathrm{\jmath}$ & $\mathrm{a} / \mathrm{\partial}$ & $\partial / \Lambda$ & $\partial / \Lambda$ & $\mathrm{a} / \partial$ & 4. ES & $\varepsilon / \mathcal{E}$ & $\mathrm{a} / \mathrm{a}$ & $\mathrm{a} / \mathrm{a}$ & $\Lambda / \Lambda$ & $a / a$ & $\mathrm{a} / \mathrm{a}$ \\
\hline 5. ES & $\partial / \mathcal{E}$ & $\mathrm{a} / \mathrm{\jmath}$ & $\mathrm{a} / \partial$ & $\Lambda / \Lambda$ & $\mathrm{a} / \Lambda$ & $\mathrm{a} / \mathrm{a}$ & 5. ES & $\varepsilon / \mathcal{E}$ & $\mathrm{a} / \mathrm{s}$ & $\mathrm{a} / \mathrm{a}$ & $\Lambda / \Lambda$ & $\mathrm{a} / \mathrm{a}$ & $a / \partial$ \\
\hline 6. ES & $\mathrm{I} / \mathcal{E}$ & $a / o$ & $\mathrm{a} / \mathrm{a}$ & $\Lambda / \Lambda$ & $\partial / \Lambda$ & $a / \partial$ & 6. ES & $\mathrm{I} / \mathcal{E}$ & $a / o$ & $\partial / a$ & ว/ว & $\mathrm{a} / \Lambda$ & $\mathrm{a} / \mathrm{a}$ \\
\hline 7. ES & $\varepsilon / \partial$ & $\mathrm{a} / \mathrm{\jmath}$ & o/a & $\mathrm{O} / \Lambda$ & $\partial / \Lambda$ & $a / \partial$ & 7. ES & $\mathrm{I} / \mathcal{E}$ & $\mathrm{a} / \mathrm{a}$ & $\mathrm{a} / \mathrm{a}$ & $\Lambda / \Lambda$ & $a / a$ & $\mathrm{a} / \mathrm{a}$ \\
\hline 8. ES & $\mathrm{I} / \mathcal{E}$ & $\mathrm{a} / \mathrm{\jmath}$ & o/a & $\Lambda / \Lambda$ & $\mathrm{a} / \Lambda$ & $\mathrm{a} / \mathrm{a}$ & 8. ES & $\mathrm{I} / 2$ & $\mathrm{a} / \mathrm{s}$ & $\mathrm{a} / \mathrm{a}$ & $\Lambda / \Lambda$ & $\mathrm{a} / \Lambda$ & $\mathrm{a} / \mathrm{a}$ \\
\hline 9. ES & $\mathrm{I} / \mathcal{E}$ & $\mathrm{a} / \mathrm{\jmath}$ & o/a & $\Lambda / \Lambda$ & $\mathrm{a} / \Lambda$ & $\mathrm{a} / \mathrm{a}$ & 9. ES & $\varepsilon / \mathcal{\varepsilon}$ & $a / o$ & $\mathrm{a} / \partial$ & $0 / 0$ & $\mathrm{a} / \mathrm{a}$ & $\mathrm{a} / \mathrm{a}$ \\
\hline 10. ES & $\varepsilon / \mathcal{E}$ & $\mathrm{a} / \mathrm{a}$ & 2/ & $\partial / \partial$ & $\varepsilon / \partial$ & $\partial / \partial$ & 10. ES & $\varepsilon / \partial$ & $a / o$ & $\mathrm{a} / \mathrm{a}$ & ว/ว & $\partial / \Lambda$ & $\mathrm{a} / \mathrm{\partial}$ \\
\hline 11. ES & $I / \partial$ & $\mathrm{a} / \mathrm{\jmath}$ & $\mathrm{a} / \mathrm{a}$ & $\Lambda / \Lambda$ & $\varepsilon / a$ & $\mathrm{a} / \mathrm{a}$ & 11. ES & $\varepsilon / \mathcal{E}$ & $\mathrm{a} / \mathrm{s}$ & $\Lambda / \mathrm{a}$ & $\Lambda / \supset$ & $a / \partial$ & $a / \partial$ \\
\hline 12. HS & $\mathrm{I} / \partial$ & $\mathrm{a} / \mathrm{\jmath}$ & $\mathrm{a} /$ & $\Lambda / \Lambda$ & $\mathrm{a} / \mathrm{a}$ & $\Lambda / \Lambda$ & 12. ES & $\varepsilon / \mathcal{\varepsilon}$ & $a / o$ & $\mathrm{a} / \mathrm{a}$ & $\Lambda / \Lambda$ & $\mathrm{a} / \Lambda$ & $a / \partial$ \\
\hline 13. HS & $\varepsilon / \varepsilon$ & $\mathrm{a} / \mathrm{a}$ & $\mathrm{a} / \mathrm{a}$ & $\Lambda / \Lambda$ & $\Lambda / \Lambda$ & $\mathrm{a} / \mathrm{a}$ & 13. ES & $\varepsilon / \mathcal{\varepsilon}$ & $a / o$ & $\partial / a$ & ว/ə & $\partial / \Lambda$ & $\mathrm{a} / \mathrm{a}$ \\
\hline 14. HS & $\partial / \partial$ & $æ / っ$ & $\mathrm{a} / \mathrm{a}$ & $\Lambda / \Lambda$ & $\Lambda / \Lambda$ & $\mathrm{a} / \mathrm{a}$ & 14. HS & $\varepsilon / \mathcal{E}$ & $a / \partial$ & o/a & $0 / 0$ & $\mathrm{a} / \Lambda$ & $\mathrm{a} / \mathrm{a}$ \\
\hline 15. HS & $\varepsilon / \varepsilon$ & $\mathrm{a} / \mathrm{\jmath}$ & $a / \partial$ & $\partial / \Lambda$ & $\partial / \Lambda$ & $a / \partial$ & 15. HS & $\varepsilon / \mathcal{\varepsilon}$ & $a / o$ & $\partial / a$ & $\Lambda / \Lambda$ & $\partial / \Lambda$ & $\mathrm{a} / \mathrm{a}$ \\
\hline 16. HS & $\varepsilon / \mathcal{\varepsilon}$ & $\mathrm{a} / \mathrm{a}$ & $\Lambda$ & $\mathrm{O} / \Lambda$ & $\mathrm{a} / \mathrm{a}$ & $\Lambda / \partial$ & 16. HS & $\varepsilon / \mathcal{E}$ & $a / o$ & $\mathrm{a} / \partial$ & $0 / 0$ & $\mathrm{a} / \mathrm{a}$ & $\mathrm{a} / \mathrm{a}$ \\
\hline 17. HS & $\varepsilon / \varepsilon$ & $\mathrm{a} / \mathrm{\jmath}$ & $\mathrm{a} / \mathrm{a}$ & $0 / \Lambda$ & $\partial / \Lambda$ & $\mathrm{a} / \mathrm{a}$ & 17. HS & $\varepsilon / \partial$ & $a / o$ & $\mathrm{a} / \mathrm{a}$ & ว/ə & $\partial / \Lambda$ & $a / \partial$ \\
\hline 18. HS & $\varepsilon / \partial$ & $a / o$ & $\mathrm{a} / \mathrm{a}$ & $\Lambda / \Lambda$ & $\partial / \Lambda$ & $\mathrm{a} / \mathrm{a}$ & 18. HS & $\varepsilon / \mathcal{E}$ & $a / o$ & $\mathrm{a} / \mathrm{a}$ & $\Lambda / \Lambda$ & $\mathrm{a} / \Lambda$ & $\mathrm{a} / \mathrm{\partial}$ \\
\hline 19. HS & $\varepsilon / \mathcal{E}$ & $æ / æ$ & $\Lambda / \Lambda$ & $0 / 0$ & $\mathrm{a} / \mathrm{\partial}$ & $\mathrm{a} / \mathrm{a}$ & 19. HS & $\varepsilon / \mathcal{E}$ & $\mathrm{a} / \mathrm{o}$ & a/a & כ/ & $\partial / \Lambda$ & $\mathrm{a} / \mathrm{a}$ \\
\hline 20. HS & $\varepsilon / \mathcal{E}$ & $\mathrm{a} / \mathfrak{x}$ & 2/a & ə/っ & $\varepsilon / \partial$ & $\mathrm{a} / \mathrm{a}$ & 20. HS & $\varepsilon / \mathcal{E}$ & $\mathrm{a} / \mathfrak{x}$ & $\Lambda / \mathrm{a}$ & $0 / 0$ & $\partial / \Lambda$ & $\mathrm{a} / \mathrm{a}$ \\
\hline 21. HS & $\varepsilon / \mathcal{E}$ & $\mathrm{a} / \partial$ & o/a & $0 / \Lambda$ & $\Lambda / \Lambda$ & $\mathrm{a} / \mathrm{a}$ & 21. HS & $\varepsilon / \mathcal{E}$ & $\mathrm{a} / \mathfrak{x}$ & $\mathrm{a} / \mathrm{a}$ & $0 / \Lambda$ & $\partial / \Lambda$ & $\mathrm{a} / \mathrm{a}$ \\
\hline 22. HS & $\varepsilon / \mathcal{E}$ & $æ / \mathrm{a}$ & $\mathrm{a} / \Lambda$ & ə/っ & $\mathrm{a} / \mathrm{a}$ & o/ & 22. HS & $\varepsilon / \mathcal{E}$ & $a / o$ & $\partial / \partial$ & $\Lambda / \Lambda$ & $\mathrm{a} / \Lambda$ & $\mathrm{a} / \mathrm{a}$ \\
\hline 23. HS & $\varepsilon / \mathcal{E}$ & $\mathrm{a} / \mathrm{\jmath}$ & כ/ & כ/っ & $\mathrm{a} / \Lambda$ & $\mathrm{a} / \partial$ & 23. HS & $\varepsilon / \mathcal{E}$ & $\mathrm{a} / \mathrm{a}$ & $\mathrm{a} / \mathrm{a}$ & $\Lambda / \Lambda$ & $\mathrm{a} / \mathrm{a}$ & $\mathrm{a} / \mathrm{a}$ \\
\hline 24. HS & $\varepsilon / \varepsilon$ & $\mathrm{a} / \mathrm{\jmath}$ & $\mathrm{a} / \mathrm{a}$ & $\Lambda / \partial$ & $\mathrm{a} / \Lambda$ & $a / \partial$ & & & & & & & \\
\hline 25. HS & $\varepsilon / \mathcal{E}$ & $\mathrm{a} / \mathrm{\jmath}$ & o/a & $\partial / \Lambda$ & $\mathrm{a} / \Lambda$ & $\mathrm{a} / \mathrm{a}$ & & & & & & & \\
\hline 26. HS & $I / O$ & $\mathrm{a} / \mathrm{\jmath}$ & $\mathrm{\partial} / \mathrm{a}$ & $\Lambda / 0$ & $\mathrm{a} / \Lambda$ & $\mathrm{a} / \mathrm{a}$ & & & & & & & \\
\hline
\end{tabular}

Table 8 Correlation of English Vowel Phonemic Awareness and Favorite Subjects (English or Non-English) of the Participants

\begin{tabular}{|c|c|c|c|c|c|c|}
\hline \multirow[b]{2}{*}{ Variables } & \multicolumn{4}{|c|}{ Favorite Subjects } & \multirow[b]{2}{*}{ Decision } & \multirow[b]{2}{*}{ Interpretation } \\
\hline & $\mathbf{N}$ & $\begin{array}{l}\text { Sig. } \\
\text { (1-tailed) }\end{array}$ & $\begin{array}{l}\text { Pearson } \\
\text { Correlation }\end{array}$ & Interpretation & & \\
\hline $\begin{array}{l}\text { English Vowel Phonemic } \\
\text { Awareness in Reading }\end{array}$ & 48 & 0.292 & -0.081 & Negative Very Low Correlation & Accept Ho & Not Significant \\
\hline $\begin{array}{l}\text { English Vowel Phonemic } \\
\text { Awareness in Speaking }\end{array}$ & 48 & 0.264 & -0.093 & Negative Very Low Correlation & Accept Ho & Not Significant \\
\hline $\begin{array}{c}\text { English Vowel Phonemic } \\
\text { Awareness in Listening }\end{array}$ & 48 & 0.267 & 0.092 & Positive Very Low Correlation & Accept Ho & Not Significant \\
\hline
\end{tabular}

Table 9 Correlation of English Vowel Phonemic Awareness and the Language Spoken by Parents of the Participants

\begin{tabular}{|c|c|c|c|c|c|c|c|}
\hline \multirow[b]{2}{*}{ Variables } & \multicolumn{5}{|c|}{ Language Spoken by Parents } & \multirow[b]{2}{*}{$\begin{array}{c}\text { Contingency } \\
\text { Coefficient }\end{array}$} & \multirow[b]{2}{*}{ Interpretation } \\
\hline & $\mathbf{N}$ & Sig. (1-tailed) & Pearson Chi-Square & Decision & Interpretation & & \\
\hline $\begin{array}{c}\text { English Vowel Phonemic } \\
\text { Awareness in Reading }\end{array}$ & 48 & 0.028 & 17.259 & Reject Ho & Significant & 0.514 & $\begin{array}{c}\text { Moderate } \\
\text { Association }\end{array}$ \\
\hline $\begin{array}{c}\text { English Vowel Phonemic } \\
\text { Awareness in Speaking }\end{array}$ & 48 & 0.000 & 24.43 & Reject Ho & Significant & 0.581 & $\begin{array}{c}\text { Moderate } \\
\text { Association }\end{array}$ \\
\hline $\begin{array}{c}\text { English Vowel Phonemic } \\
\text { Awareness in Listening }\end{array}$ & 48 & 0.189 & 11.232 & Accept Ho & Not Significant & & ------ \\
\hline
\end{tabular}

The results partly support the observation that the academic level is related to language acquisition (Jones and McLachlan, 2009). The premise that if Filipino children thought that "their English is good enough to graduate from high school, it should be good enough to enter the university without further testing" (Thompson 2003) is borne out. This does not augur well with the Faculty whose phonemic awareness seems not to be affected by their academic achievement. Table 7 shows most of the male participants pronounced the vowel in the word read and serenity as [E] compared with that of female participants. A number of female participants pronounced it [I]. For the initial vowel in verbal phrase acting up, which is supposed to be [æ], many of the participants pronounced it [a]; for the same vowel in the word laughing, a number of participants pronounced it [0]. This indicates that for these participants [æ] can be read as [0]. Both of these vowels are produced with the lowering of the tongue though the lower jaw is moved either forward, or steady, or a bit backward. For the words but and cut, the participants pronounced the vowel either [a] or [ə]. Whereas the word but sounds more as bat (an implement in hitting ball in baseball), the vowel sounding like a low middle, the vowel in the word $c \boldsymbol{u} t$ sounds more less round, being a center middle

vowel. With regard to the words thought and caught, Table 13 shows that a number of participants pronounced the vowel as $[\Lambda]$. Though some pronounced the vowel in these words as [॰], a few pronounced it as [ə]. This suggests that for 
English, a language used in the classroom instruction and discussion, is different from that one spoken at home,

Table 10 Comparison of Vowel Segments of Participants in Vowel Phonemic Awareness in Listening

\begin{tabular}{|c|c|c|c|c|c|c|c|c|c|c|c|}
\hline \multicolumn{6}{|c|}{ Elementary School } & \multicolumn{6}{|c|}{ High School } \\
\hline$\varepsilon$ & $æ$ & 0 & $\Lambda$ & $\mathrm{a}$ & ə & $\varepsilon$ & $æ$ & 0 & $\Lambda$ & $\mathrm{a}$ & $\partial$ \\
\hline$\varepsilon$ & $æ$ & 0 & $\Lambda$ & $\mathrm{a}$ & 0 & $\varepsilon$ & 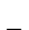 & $\Lambda$ & $\Lambda$ & $\mathrm{a}$ & $\mathrm{a}$ \\
\hline$\varepsilon$ & $æ$ & 0 & $\Lambda$ & $\mathrm{a}$ & $æ$ & $\varepsilon$ & $æ$ & $\Lambda$ & $\Lambda$ & $\mathrm{a}$ & $\partial$ \\
\hline$\varepsilon$ & $æ$ & 0 & $\mathrm{a}$ & $\mathrm{a}$ & $æ$ & I & 0 & 0 & $\Lambda$ & $\mathrm{a}$ & 0 \\
\hline$\varepsilon$ & $æ$ & $\mathrm{a}$ & $\Lambda$ & $\mathrm{a}$ & ə & $\varepsilon$ & $æ$ & A & $\Lambda$ & $\mathrm{a}$ & ə \\
\hline$\varepsilon$ & $æ$ & 0 & $\Lambda$ & $\varepsilon$ & $\partial$ & $\varepsilon$ & 0 & 0 & $\Lambda$ & $\mathrm{a}$ & $\mathrm{a}$ \\
\hline$\varepsilon$ & $æ$ & 0 & $\Lambda$ & $\mathrm{a}$ & $æ$ & $\varepsilon$ & a & 0 & $\Lambda$ & ə & 0 \\
\hline$\varepsilon$ & 0 & $\mathrm{a}$ & $\Lambda$ & $\mathrm{a}$ & o & $\varepsilon$ & a & 0 & a & $\mathrm{a}$ & 0 \\
\hline$\varepsilon$ & $æ$ & $\Lambda$ & æ & $\mathrm{a}$ & 0 & $\varepsilon$ & $æ$ & 0 & $\Lambda$ & $\mathrm{a}$ & $\partial$ \\
\hline$\varepsilon$ & $æ$ & $\Lambda$ & æ & $\mathrm{a}$ & 0 & $\varepsilon$ & 0 & 0 & $\Lambda$ & $\mathrm{a}$ & 0 \\
\hline$\varepsilon$ & $æ$ & 0 & $\mathrm{a}$ & $\mathrm{a}$ & $æ$ & $\varepsilon$ & $æ$ & 0 & $\Lambda$ & $\mathrm{a}$ & ə \\
\hline$\varepsilon$ & $\mathrm{a}$ & 0 & $\mathrm{a}$ & $\mathrm{a}$ & 0 & $\partial$ & $æ$ & 0 & $\Lambda$ & $\mathrm{a}$ & $\partial$ \\
\hline$\varepsilon$ & 0 & $\Lambda$ & $\Lambda$ & $\mathrm{a}$ & 0 & $\varepsilon$ & $æ$ & 0 & $\Lambda$ & $\mathrm{a}$ & $\mathrm{a}$ \\
\hline$\varepsilon$ & 0 & 0 & $\Lambda$ & $\mathrm{a}$ & ə & $\varepsilon$ & o & A & $\Lambda$ & $\mathrm{a}$ & ə \\
\hline$\varepsilon$ & æ & $\mathrm{a}$ & $\Lambda$ & $\mathrm{a}$ & $\partial$ & $\varepsilon$ & $\mathrm{a}$ & 0 & $\Lambda$ & $\varepsilon$ & $\partial$ \\
\hline$\varepsilon$ & $æ$ & $\mathrm{a}$ & $\Lambda$ & $\mathrm{a}$ & $\partial$ & $\varepsilon$ & $æ$ & 0 & $\Lambda$ & $\mathrm{a}$ & $\mathrm{a}$ \\
\hline$\varepsilon$ & 0 & 0 & $\Lambda$ & $\mathrm{a}$ & $\mathrm{a}$ & $\varepsilon$ & $\mathrm{a}$ & 0 & $\Lambda$ & $\mathrm{a}$ & 0 \\
\hline$\varepsilon$ & $æ$ & 0 & $\Lambda$ & $\mathrm{a}$ & $\partial$ & $\varepsilon$ & $æ$ & 0 & $\Lambda$ & $\mathrm{a}$ & $\partial$ \\
\hline$\varepsilon$ & $\mathrm{a}$ & $\Lambda$ & æ & $\Lambda$ & 0 & $\varepsilon$ & $æ$ & 0 & $\Lambda$ & $\mathrm{a}$ & $\partial$ \\
\hline$\varepsilon$ & $æ$ & $\mathrm{a}$ & $\Lambda$ & $\mathrm{a}$ & $æ$ & $\varepsilon$ & $æ$ & A & $\Lambda$ & $\mathrm{a}$ & $\partial$ \\
\hline$\varepsilon$ & $æ$ & 0 & $\Lambda$ & $\mathrm{a}$ & ə & $\varepsilon$ & $æ$ & 0 & $\Lambda$ & $\mathrm{a}$ & $æ$ \\
\hline$\varepsilon$ & $æ$ & 0 & $\Lambda$ & $\mathrm{a}$ & ə & $\varepsilon$ & $\mathrm{a}$ & 0 & $\Lambda$ & $\mathrm{a}$ & $\partial$ \\
\hline$\varepsilon$ & 0 & 0 & $\Lambda$ & $\mathrm{a}$ & 0 & $\varepsilon$ & $\mathrm{a}$ & 0 & $\Lambda$ & $\varepsilon$ & 0 \\
\hline$\varepsilon$ & 0 & $\mathrm{a}$ & æ & $\mathrm{a}$ & 0 & $\varepsilon$ & $æ$ & 0 & $\Lambda$ & $\mathrm{a}$ & $\partial$ \\
\hline$\varepsilon$ & $æ$ & 0 & $\Lambda$ & $\mathrm{a}$ & ə & $\varepsilon$ & $æ$ & A & $\Lambda$ & $\mathrm{a}$ & ว \\
\hline$\varepsilon$ & 0 & 0 & $\Lambda$ & $æ$ & $\mathrm{a}$ & $\varepsilon$ & $æ$ & 0 & $\Lambda$ & $a$ & $\partial$ \\
\hline$\varepsilon$ & $æ$ & 0 & $\Lambda$ & $\mathrm{a}$ & $\mathrm{a}$ & & & & & & \\
\hline$\varepsilon$ & 0 & $\mathrm{a}$ & $\Lambda$ & $\mathrm{a}$ & Ә & & & & & & \\
\hline$\varepsilon$ & 0 & 0 & $\Lambda$ & $\mathrm{a}$ & ə & & & & & & \\
\hline$\varepsilon$ & A & 0 & $\Lambda$ & $\varepsilon$ & ə & & & & & & \\
\hline$\varepsilon$ & $\nexists$ & 0 & $\Lambda$ & $\mathrm{a}$ & $\mathrm{a}$ & & & & & & \\
\hline
\end{tabular}

pronunciation of the back mid-low less round vowel, [0], they sound more as schwa vowels.

For the words sergeant and cot, the initial vowel was pronounced more as [a], [ə], $[\Lambda]$, and $[\mathcal{E}]$. Whereas the vowel in the word cot was pronounced more as $[\Lambda]$, the initial vowel in the word sergeant was more variable. Table 7 shows that for the words alone and sofa, the initial and final vowel /a/ was pronounced by most participants as [a]. This suggests the intervention of a feature of Tagalog (L1) in the production of $\mathrm{L} 2$, and this is making the syllable stands out in every vowelconsonant-vowel-consonant and consonant-vowel-consonantvowel patterns.

As revealed Table 8, on Pearson correlations of the English vowel phonemic awareness and the favorite subjects (English or Non-English) of JRU basic education honor students and selected Faculty, reading obtained -0.081 , speaking -0.093 , and listening 0.092. The phonemic awareness in all the speech components of the participants as related to their favorite subject is negative very low correlation; it is not significant.

On Pearson correlations of the English vowel phonemic awareness and the language spoken by parents of JRU basic education honor students and selected Faculty, reading obtained 17.259, speaking 24.43, and listening 11.232. Whereas reading and speaking are significant, listening is not significant. Nonetheless, both of those speech components have moderate association as their contingency coefficients were 0.514 and 0.581 respectively as shown in Table 9. Concluding similarly, Barone (2006) observed very young elementary graders, "regardless of home language, had not acquired academic language."
Wheth er it is the native variety or ESL. Nonetheless, as revealed in Table 7, 26.3 of participants had parents who speak both Non-Tagalog vernaculars, whereas 33.3 of them had parents who speak Tagalog. It is unexpected then the results being significant on English vowel phonemic awareness in reading and speaking. For the word bed, both most of male and female participants pronounced its vowel as [E] as revealed in Table 10. This English vowel is in the national language which is being taught in school. Exposure to this makes the participants familiar with it. Thus, they had no difficulty in producing it. With regard to the vowel [æ] in the word laugh, a number of the participants heard it as [0]; a few aurally processed it as [a]. Though all are low vowels, they are distinguished from each in terms of whether the lower jaw is moved forward or backward; whether the tip, or middle, or back of the tongue is raised. The vowels [æ] and [0] are not in the inventory of the L1 of participants. Nonetheless, the elementary school participants heard it more as [0] as compared to high school which aurally processed it as [a]. Table 10 reveals that most participants heard it as [0] for the word caught. They also reported hearing $[\Lambda]$ and [a]. This implies that Philippine English contains a vowel from SAE. With regard to the word bus, the participants heard it as $[\Lambda]$. It sounds like the participants were familiar with back low, more open vowel. As expected, almost all of participants could distinguish [a]. This vowel is universal, and is easy to recognize. A number of participants indicated hearing [0], whereas some chose [æ], with very few as [a]. Not a few reported [ə] for the initial vowel of the word alike. This suggests that the initial slot of the word and the vowel [ə] can result in phonemic variability among participants. 
Table 11Comparison of Vowel Segments of Participants in Vowel Phonemic Awareness in Speaking

\begin{tabular}{|c|c|c|c|c|c|c|c|c|c|c|c|c|c|}
\hline & \multicolumn{6}{|c|}{ Elementary school } & & \multicolumn{6}{|c|}{ High school } \\
\hline & $\varepsilon$ & $\mathfrak{x}$ & $\boldsymbol{\Lambda}$ & $\mathbf{0}$ & $\mathbf{a}$ & O & & $\varepsilon$ & E & $\boldsymbol{A}$ & $\mathbf{0}$ & $\mathbf{A}$ & O \\
\hline $\begin{array}{l}\text { F-Tagalog } \\
\text { M-Tagalog }\end{array}$ & ə/ə & $\mathrm{a} / \mathrm{a}$ & $\Lambda$ & $\mathrm{O} / \Lambda$ & $\mathrm{a} / \mathrm{a}$ & $\Lambda / \Lambda$ & $\begin{array}{l}\text { F-Tagalog } \\
\text { M-Tagalog }\end{array}$ & o/a & $æ / ə$ & $\partial$ & o/ə & $\mathrm{a} / \mathrm{a}$ & ə/ə \\
\hline $\begin{array}{l}\text { F-Tagalog } \\
\text { M-Tagalog }\end{array}$ & $\partial / \varepsilon$ & $æ / \mathrm{a}$ & $\mathrm{a}$ & $\mathrm{O} / \Lambda$ & $\mathrm{a} / \mathrm{a}$ & ə/ə & $\begin{array}{l}\text { F- Tagalog } \\
\text { M-Tagalaog }\end{array}$ & $\varepsilon / \varepsilon$ & $æ / a$ & $\Lambda$ & $0 / 0$ & $\mathrm{a} / \mathrm{a}$ & $\partial / \partial$ \\
\hline $\begin{array}{l}\text { F-Tagalog } \\
\text { M-Tagalog }\end{array}$ & ə/ع & $\mathrm{a} / \mathrm{a}$ & $\mathrm{a}$ & $\mathrm{O} / \Lambda$ & $\mathrm{a} / \mathrm{a}$ & $\Lambda / \Lambda$ & $\begin{array}{l}\text { F-Tagalog } \\
\text { M-Tagalog }\end{array}$ & $\varepsilon / \varepsilon$ & $\mathrm{a} / \mathrm{a}$ & $\mathrm{a}$ & $\rho / \Lambda$ & $\mathrm{a} / \mathrm{a}$ & ə/ə \\
\hline $\begin{array}{l}\text { F-Tagalog } \\
\text { M-Tagalog }\end{array}$ & ə/ع & $\mathrm{a} / \mathrm{a}$ & $\mathrm{a}$ & $\mathrm{O} / \Lambda$ & $\mathrm{a} / \mathrm{a}$ & $\partial / \Lambda$ & $\begin{array}{l}\text { F-Tagalog } \\
\text { M-Tagalog }\end{array}$ & $\partial / \varepsilon$ & $\mathrm{a} / \mathrm{a}$ & $\mathrm{a}$ & $\mathrm{O} / \Lambda$ & $\mathrm{a} / \mathrm{a}$ & ว/ə \\
\hline $\begin{array}{l}\text { F-Tagalog } \\
\text { M-Tagalog }\end{array}$ & $\partial / \varepsilon$ & $\mathrm{a} / \mathrm{a}$ & $\mathrm{a}$ & $\mathrm{O} / \Lambda$ & $\mathrm{a} / \mathrm{a}$ & $\partial / \Lambda$ & $\begin{array}{l}\text { F-Tagalog } \\
\text { M-Tagalog }\end{array}$ & ə/ə & $\mathrm{a} / \mathrm{a}$ & $\mathrm{a}$ & $\mathrm{O} / \Lambda$ & $\mathrm{a} / \mathrm{a}$ & $\Lambda / \Lambda$ \\
\hline $\begin{array}{l}\text { F-Tagalog } \\
\text { M-Tagalog }\end{array}$ & $\varepsilon / \varepsilon$ & $\mathrm{a}$ & $\mathrm{a}$ & $\mathrm{O} / \Lambda$ & $\varepsilon / \partial$ & $\mathrm{a} / \curvearrowright$ & $\begin{array}{l}\text { F-Tagalog } \\
\text { M-Tagalog }\end{array}$ & $\partial / \varepsilon$ & $\mathrm{a} / \mathrm{a}$ & $\mathrm{a}$ & $\mathrm{O} / \Lambda$ & $\mathrm{a} / \mathrm{a}$ & $\Lambda / \Lambda$ \\
\hline $\begin{array}{l}\text { F-Tagalog } \\
\text { M-Tagalog }\end{array}$ & ə/ع & $\mathrm{a} / \mathrm{a}$ & ə & $\mathrm{o} / \mathrm{a}$ & $\mathrm{a} / \mathrm{a}$ & $\Lambda / \curvearrowright$ & $\begin{array}{l}\text { F-Tagalog } \\
\text { M-Tagalog }\end{array}$ & $\varepsilon / \varepsilon$ & $\mathrm{a} / \mathrm{a}$ & $\mathrm{a}$ & $\mathrm{o} / \curvearrowright$ & $\mathrm{a} / \mathrm{a}$ & $\Lambda / \Lambda$ \\
\hline $\begin{array}{l}\text { F-Tagalog } \\
\text { M-Tagalog }\end{array}$ & $\varepsilon / \varepsilon$ & $\mathrm{a} / \mathrm{a}$ & $\mathrm{a}$ & $\mathrm{O} / \Lambda$ & $\mathrm{a} / \mathrm{a}$ & $\Lambda / \Lambda$ & $\begin{array}{l}\text { F-Tagalog } \\
\text { M-Tagalog }\end{array}$ & $\partial / \varepsilon$ & o/a & $\mathrm{a}$ & $\partial / \Lambda$ & $\mathrm{a} / \mathrm{a}$ & $\partial / \Lambda$ \\
\hline $\begin{array}{l}\text { F-Tagalog } \\
\text { M-Tagalog }\end{array}$ & $\varepsilon / \varepsilon$ & $\mathrm{a} / \mathrm{a}$ & $\mathrm{a}$ & $\mathrm{O} / \partial$ & $\mathrm{a} / \mathrm{a}$ & $\Lambda / \curvearrowright$ & $\begin{array}{l}\text { F-Tagalog } \\
\text { M-Tagalog }\end{array}$ & $\varepsilon / \varepsilon$ & $\mathrm{a} / \mathrm{a}$ & $\mathrm{a}$ & $\mathrm{O} / \Lambda$ & $\mathrm{a} / \mathrm{a}$ & $\Lambda / \partial$ \\
\hline $\begin{array}{l}\text { F-Tagalog } \\
\text { M-Tagalog }\end{array}$ & $\varepsilon / \varepsilon$ & $\mathrm{a} / \mathrm{a}$ & $\mathrm{a}$ & $\mathrm{O} / \partial$ & $\mathrm{a} / \mathrm{a}$ & $\Lambda / \Lambda$ & & & & & & & \\
\hline $\begin{array}{l}\text { F-Tagalog } \\
\text { M-Tagalog }\end{array}$ & $\varepsilon / \varepsilon$ & $\mathrm{a} / \mathrm{a}$ & $\mathrm{a}$ & $\mathrm{O} / \Lambda$ & $\mathrm{a} / \mathrm{a}$ & $\Lambda / \partial$ & & & & & & & \\
\hline $\begin{array}{l}\text { F-Tagalog } \\
\text { M-Tagalog }\end{array}$ & ə/ع & ə/a & $\partial$ & $\mathrm{O} / \Lambda$ & $\mathrm{a} / \mathrm{a}$ & ə/ə & & & & & & & \\
\hline $\begin{array}{l}\text { F-Tagalog } \\
\text { M-Tagalog }\end{array}$ & ə/ع & $\mathrm{a} / \mathrm{a}$ & $\mathrm{a}$ & $\mathrm{O} / \partial$ & $\mathrm{a} / \mathrm{a}$ & ə/ə & & & & & & & \\
\hline $\begin{array}{c}\text { F-Bisaya } \\
\text { M-Tagalog }\end{array}$ & $\varepsilon / \varepsilon$ & $\mathrm{a} / \mathrm{a}$ & $\mathrm{a}$ & $\mathrm{\rho} / \Lambda$ & $\mathrm{a} / \mathrm{a}$ & $\Lambda / \Lambda$ & $\begin{array}{c}\text { F: Tagalog } \\
\text { M: Pampanga }\end{array}$ & $\varepsilon / \varepsilon$ & $æ / æ$ & $\mathrm{a}$ & $\partial / \Lambda$ & $\mathrm{a} / \mathrm{a}$ & ə/ə \\
\hline $\begin{array}{l}\text { F-Tagalog } \\
\text { M: Ilonggo }\end{array}$ & ə/ع & $\mathrm{a} / \mathrm{a}$ & $\mathrm{a}$ & $\mathrm{O} / \Lambda$ & $\mathrm{a} / \mathrm{a}$ & $\Lambda / \Lambda$ & $\begin{array}{l}\text { F- Tagalog } \\
\text { M-Ilocano }\end{array}$ & $\partial / \varepsilon$ & $\mathrm{a} / \mathrm{a}$ & $\mathrm{a}$ & $\mathrm{o} / \partial$ & $\mathrm{a} / \mathrm{a}$ & $\partial / \Lambda$ \\
\hline $\begin{array}{c}\text { F-Tagalog } \\
\text { M-Pangalatok }\end{array}$ & $\varepsilon / \varepsilon$ & æ/æ & $\mathrm{a}$ & $0 / 0$ & $\mathrm{a} / \mathrm{a}$ & ə/ə & $\begin{array}{c}\text { F-Tagalog } \\
\text { M-Bicol }\end{array}$ & $\partial / \varepsilon$ & $\mathrm{a} / \mathrm{a}$ & $\mathrm{a}$ & $\mathrm{O} / \Lambda$ & $\mathrm{a} / \mathrm{a}$ & $\partial / \Lambda$ \\
\hline $\begin{array}{l}\text { F- Bisaya } \\
\text { M-Tagalog }\end{array}$ & ə/ & $\mathrm{a} / \mathrm{a}$ & $\mathrm{a}$ & $\mathrm{O} / \partial$ & $\mathrm{a} / \mathrm{a}$ & ə/ə & $\begin{array}{c}\text { F-Tagalog } \\
\text { M-Pangalatok }\end{array}$ & $\varepsilon / \varepsilon$ & $æ / æ$ & $\mathrm{a}$ & o/ & $\mathrm{a} / \mathrm{a}$ & ə/ə \\
\hline $\begin{array}{c}\text { F- Tagalog } \\
\text { M-Bisaya }\end{array}$ & ə/ع & $\mathrm{a} / \mathrm{a}$ & $\Lambda$ & ग/ə & $\mathrm{a} / \mathrm{a}$ & $\Lambda / \Lambda$ & $\begin{array}{c}\text { F- Bisaya } \\
\text { M-Tagalog }\end{array}$ & ə/ & $\mathrm{a} / \mathrm{a}$ & $\mathrm{a}$ & $0 / \partial$ & $\mathrm{a} / \mathrm{a}$ & $\partial / \partial$ \\
\hline $\begin{array}{c}\text { F-Waray } \\
\text { M-Tagalog }\end{array}$ & o/ع & $\mathrm{a} / \mathrm{a}$ & $\mathrm{a}$ & $\mathrm{\partial} / \Lambda$ & $\mathrm{a} / \mathrm{a}$ & $\Lambda / \Lambda$ & $\begin{array}{l}\text { F-Waray } \\
\text { M-Tagalog }\end{array}$ & $\partial / \varepsilon$ & $\mathrm{a} / \mathrm{a}$ & $\mathrm{a}$ & $\partial / \Lambda$ & $\mathrm{a} / \mathrm{a}$ & $\Lambda / \Lambda$ \\
\hline $\begin{array}{l}\text { F-Tagalog } \\
\text { M-Bisaya }\end{array}$ & $\varepsilon / \varepsilon$ & $\mathrm{a} / \mathrm{a}$ & $\partial$ & o/ & $\mathrm{a} / \mathrm{a}$ & ə/っ & $\begin{array}{l}\text { F-Tagalog } \\
\text { M-Bisaya }\end{array}$ & $\varepsilon / \varepsilon$ & $\mathrm{a} / \mathrm{a}$ & ə & o/ə & $\mathrm{a} / \mathrm{a}$ & ə/ə \\
\hline $\begin{array}{l}\text { F-Tagalog } \\
\text { M-Ilonggo }\end{array}$ & ə/ع & $\mathrm{a} / \mathrm{a}$ & $\mathrm{a}$ & $\mathrm{O} / \Lambda$ & $\mathrm{a} / \mathrm{a}$ & $\Lambda / \Lambda$ & $\begin{array}{c}\text { F-Bisaya } \\
\text { M-Tagalog }\end{array}$ & $\partial / \varepsilon$ & כ/ə & $\mathrm{a}$ & $\mathrm{o} / \partial$ & $\mathrm{a} / \mathrm{a}$ & $\Lambda / \partial$ \\
\hline $\begin{array}{l}\text { F-Tagalog } \\
\text { M-Kapamp }\end{array}$ & ə/ع & $\mathrm{a} / \mathrm{a}$ & $\mathrm{a}$ & $\mathrm{O} / \Lambda$ & $\mathrm{a} / \mathrm{a}$ & ə/ə & $\begin{array}{l}\text { F-Ilocano } \\
\text { M-Ilocano }\end{array}$ & $\varepsilon$ & $æ$ & 0 & $\wedge$ & $\mathrm{a}$ & ə \\
\hline $\begin{array}{l}\text { F- Tagalog } \\
\text { M-Pangala }\end{array}$ & $\varepsilon / \varepsilon$ & $\mathrm{a} / \mathrm{a}$ & $\mathrm{a}$ & $\mathrm{O} / \Lambda$ & $\mathrm{a} / \mathrm{a}$ & $\Lambda / \curvearrowright$ & $\begin{array}{l}\text { F-Bisaya } \\
\text { M-Bisaya }\end{array}$ & $\varepsilon$ & $æ$ & 0 & $\Lambda$ & $\mathrm{a}$ & $æ$ \\
\hline $\begin{array}{l}\text { F-Ilonggo } \\
\text { M-Bisaya }\end{array}$ & ə/ə & $\mathrm{a} / \mathrm{\partial}$ & $\mathrm{a}$ & $\mathrm{O} / \Lambda$ & $\mathrm{a} / \mathrm{a}$ & ə/ə & $\begin{array}{l}\text { F-Ilonggo } \\
\text { M-Bisaya }\end{array}$ & $\partial / \partial$ & $\mathrm{a} / \mathrm{a}$ & $\mathrm{a}$ & $\mathrm{o} / \Lambda$ & $\mathrm{a} / \mathrm{a}$ & ə/ə \\
\hline $\begin{array}{l}\text { F-Ilonggo } \\
\text { M-Bisaya }\end{array}$ & ว/ə & $\mathrm{a} / \mathrm{\partial}$ & $\mathrm{a}$ & $\mathrm{O} / \Lambda$ & $\mathrm{a} / \mathrm{a}$ & ə/ə & $\begin{array}{l}\text { F-Bisaya } \\
\text { M-Bisaya }\end{array}$ & $\partial / \varepsilon$ & $\mathrm{a} / \mathrm{a}$ & $\mathrm{a}$ & $\mathrm{o} / \Lambda$ & $\mathrm{a} / \mathrm{a}$ & $\Lambda / \curvearrowright$ \\
\hline $\begin{array}{l}\text { F-Bisaya } \\
\text { M-Bisaya }\end{array}$ & 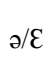 & $\mathrm{a} / \mathrm{a}$ & $\mathrm{a}$ & $\mathrm{O} / \Lambda$ & $\mathrm{a} / \mathrm{a}$ & $\Lambda / \curvearrowright$ & $\begin{array}{l}\text { F-Isabela } \\
\text { M-ilocos }\end{array}$ & $\partial / \mathcal{E}$ & $\mathrm{a} / \mathrm{a}$ & ə & $\mathrm{o} / \Lambda$ & $\mathrm{a} / \mathrm{a}$ & $\partial / \partial$ \\
\hline $\begin{array}{l}\text { F-Ilonggo } \\
\text { M-Bisaya }\end{array}$ & $\partial / \partial$ & $\mathrm{a} / \partial$ & $\mathrm{a}$ & $\mathrm{O} / \Lambda$ & $\mathrm{a} / \mathrm{a}$ & ə/ə & $\begin{array}{l}\text { M: Hiligaynon } \\
\text { F: Ilongo }\end{array}$ & $\varepsilon / I$ & $\mathrm{a} / \mathrm{a}$ & $\mathrm{a}$ & $\mathrm{o} / \Lambda$ & $\mathrm{a} / \mathrm{a}$ & $\Lambda / \Lambda$ \\
\hline $\begin{array}{c}\text { F-Nihonggo } \\
\text { M-Bisaya }\end{array}$ & ə/E & $\mathrm{a} / \mathrm{a}$ & $\mathrm{a}$ & $\Lambda / \partial$ & $\mathrm{a} / \mathrm{a}$ & $\Lambda / \Lambda$ & $\begin{array}{c}\text { F: Cebuano } \\
\text { M: Pampanga }\end{array}$ & $\varepsilon / \partial$ & $\mathrm{a} / \mathrm{a}$ & $\mathrm{a}$ & $\mathrm{a} / \Lambda$ & $\mathrm{a} / \mathrm{a}$ & $\partial / \partial$ \\
\hline $\begin{array}{l}\text { F-English } \\
\text { M-Bisaya }\end{array}$ & o/E & o/ə & $\partial$ & o/ə & $\varepsilon / \mathrm{o}$ & ə/ə & $\begin{array}{l}\text { F-Ilocano } \\
\text { M-Bisaya }\end{array}$ & $\mathrm{a} / \mathcal{E}$ & $\mathrm{a} / \mathrm{a}$ & $\mathrm{a}$ & $\mathrm{o} / \Lambda$ & $\mathrm{a} / \mathrm{a}$ & $\partial / \partial$ \\
\hline $\begin{array}{l}\text { F-Ilocano } \\
\text { M-Ilocano }\end{array}$ & 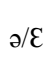 & $\mathrm{a} / \mathrm{a}$ & $\mathrm{a}$ & $\mathrm{O} / \mathrm{\partial}$ & $\mathrm{a} / \mathrm{a}$ & ə/っ & & & & & & & \\
\hline
\end{tabular}

Table 11 shows that for the word dead most participants with parents who both speak Tagalog pronounced the vowel as [ə], whereas for the word fled $[\mathcal{E}]$. The vowel [E] for the word fled is a morphological marker of past tense. The participants had to pronounce it as a front mid-low lax vowel to distinguish it from its present form. Those with parents who speak other non-Tagalog vernaculars pronounced the vowel for these words as [ə]. For the vowel in the words $d a d$ and mad, most of the participants pronounced it as [a], a low center vowel.
The vowel $[æ]$ is not found in the vowel inventory of Tagalog. Growing up, exposed to the speech of their parents withregard to not really hearing this vowel, could have made them choose the vowel [a] as the most similar to the vowel [æ].

With regard to the vowel $[\Lambda]$ in the word cut, most of the participants pronounced it as [a], whereas the rest of the few articulated it as [ə]. Most of Filipinos struggled in pronouncing the schwa vowels. The participants' exposure to their parents' vernaculars did not help in making them catch these vowel segments. For the word sawed and $b \mathbf{a} l l$, a number 
of participants with parents both speaking Tagalog pronounced the vowel as either [o] or $[\Lambda]$. Those with parents speaking other non-Tagalog vernaculars pronounced it almost the same, though some articulated it as [ə]. Some participants pronounced it as [0], particularly with word awed. Just like the participants 'struggling' with the schwa [ə] on the initial slot of the word (alike), they might have found it a bit hard to pronounce this vowel on its initial slot.

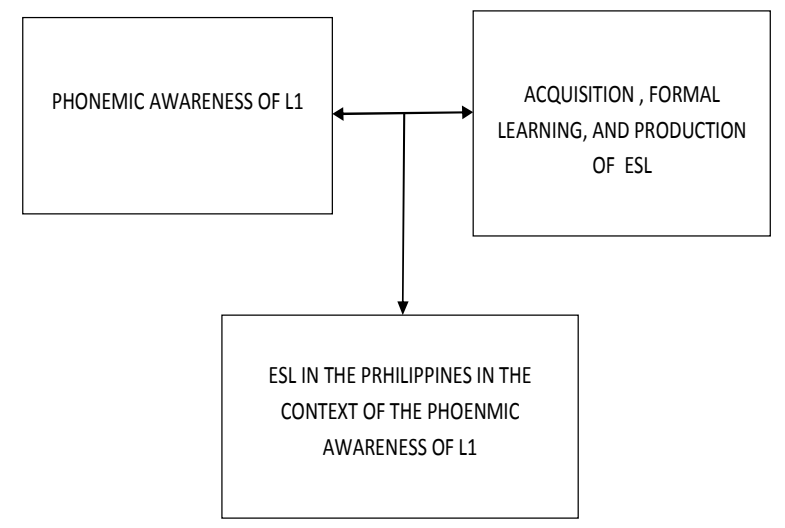

Figure 1 ESL in the Context of Philippine Phonemic Awareness of L1

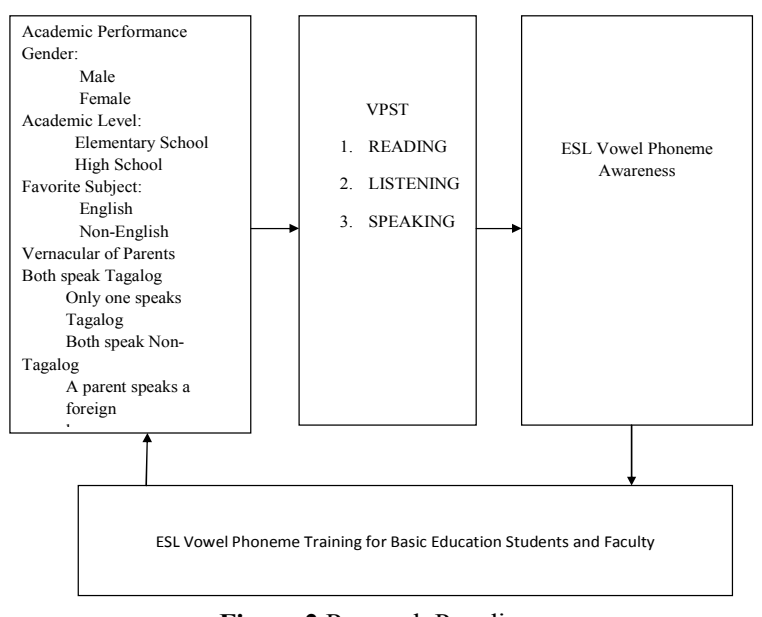

Figure 2 Research Paradigm

Almost all of the participants, regardless of the vernaculars spoken by the parents, for the vowel in the words army and $c \mathbf{a r}$, pronounced it as [a]. For the words symphony and melody, Table 11 reveals that participants with parents both speaking Tagalog, or at least one Non-Tagalog, would either pronounce the vowel as [ə] or $[\Lambda]$. Those with parents speaking Non-Tagalog pronounced it as [ə].

\section{Conclusion and Recommendation}

\section{Based on the discussion of the findings above, the following conclusions are drawn}

Almost all of the honor basic education students had very satisfactory phonemic awareness. They could distinguish English vowels from each other. Almost all of JRU basic education students showed very satisfactory phonemic awareness. They could recognize the difference among problematic English sounds. They could speak English with vowel phonemes functionally. The phonemic awareness of participants in reading, speaking, and listening is not related to their academic performance though. Being male or female seems to affect how JRU honor students and selected Faculty recognize and distinguish English vowels. A number of the JRU honor students could recognize and distinguish vowel phonemes as they went higher in academic level.

The participants' vowel [æ] could be read as [o]. Both of these vowels are produced with the lowering of the tongue though the lower jaw is moved either forward, or steady, or a bit backward. There is an indication of the intervention of a feature of Tagalog (L1) in the production of L2, and this is making the syllable stands out in every vowel-consonantvowel-consonant and consonant-vowel-consonant-vowel patterns.

The vowels [æ] and [0] are not in the inventory of the L1 of participants. Nonetheless, the elementary school participants heard it more as [0] as compared to high school which aurally processed it as [a]. The initial slot of the word and the vowel [ə] can result in variability among participants' auditory recognition. For the vowel in the words $d \mathbf{a} d$ and $m \mathbf{a} d$, most of the participants pronounce it as [a], a low center vowel. Some participants pronounce it as [0], particularly with word awed. Just like the participants 'struggling' with the schwa [ə] on the initial slot of the word (alike), they might have found it a bit hard to pronounce this vowel on its initial slot.

\section{Based on the conclusions formulated, the following recommendations are proposed}

Enhancement of English curriculum that is both enticing to male and female learners. Establishment of a pool of research on English phonemes that be a source of data for the development of teaching materials for English. These materials should meet the interest and needs of all types of learners.

Investigation should be pursued as to the relationship between literacy skills and academic performance. The phonemic awareness of underachieving learners in relation to average and highly performing learners should be explored.

Introduction of Standard American English vowel segments should be done gradually in basic education before the year level of implementation of the ESL curriculum. Further study on phonemic awareness as to the role played by the slot occupied by the vowel in a word and the natural speech context should be carried out.

\section{Bibliography}

Barone, Diane M. (2006). Narrowing the Literacy Gap: What Works in High-Poverty Schools. USA: Guilford Press.

Bautista, Ma. (2001). Lourdes S. Attitudes of Selected Luzon University Students and Faculty Toward Philippine English. The Philippine Association for Language Teaching Philippines. Rosario Maminta in Focus: Selected Writings in Applied Linguistics. The Philippine Association for Language Teaching Philippines: Asian Graphics Printing, Inc.

Bohn, Ocke-Schwen and Munro, Murray. (2007). Language Experience in Second Language Speech Learning: In Honor of James Emil Flege -Amsterdam: John Benjamins Publishing Company.

Collins B.M. and Inger M. Leidin. (2003). Phonetics of English and Dutch. NLD: Brill Academic Publishers. 
Combista, Delia. (1995). The Interdependence of The Cognitive Academic Language Proficiency (CALP) in Cebuano and English in Language Science. UP Diliman: Thesis, March.

Dalton, Christine and Barbara Seidlhofer. (1994). Pronunciation. Oxford: Oxford University Press.

David, Wood. (2010). Formulaic Language and Second Language Speech Fluency: Background, Evidence, and Classroom Applications. London: Continuum International Publishing.

Deano, Raidis. (2006). Phonemic Awareness and Word Reading in English and Filipino of First Graders. UP Diliman: MA Thesis, October.

De los Reyes-Videheecharoen. (2000). A Comparative Analysis of Classroom Interactions of Native and Non-Native English Teachers with Their Thai Learners. UP Diliman: PhD Thesis.

Diaz, Arlene. (1995). Patterns of Communicative Strategies Employed by Second Language Learners. UP Diliman: Thesis, August.

Hansen Edwards, Jette G. (2008). "Social factors and variation in production in L2 phonology"in (Eds.)Edwards Hansen, Jette and Zampini, Mary L.Phonology and Second Language Acquisition. Amsterdam: John Benjamins Publishing Co.

Flege, James Emil. (May 2011). "English vowel productions by Dutch talkers: more evidence for the "similar" vs "new" distinction" in Walter De Gruyter (Ed.) Studies on Language Acquisition [SOLA]: Second Language Speech: Structure and Process.

Garcia-Aranas, Patricia. (1988). A Characterization of the English Spoken by English and Mathematics Teacher in the Tertiary Level of Education in Selected Universities in Metro Manila. UP System: $\mathrm{PhD}$ Dissertation.

Goodwin, Janet. (2005). Teaching Pronunciation. Quezon City: Wadsworth.

Guzman, M., R. Alcantara, P. Arinto, E. Barios, J. Malicsi, N. Ocampo, M.C. Marcial. (1998). Living Language: Assessment of Language Proficiency and Needs in the Professions and in the Workplace. QC: UP Office of Research Coordination.

Gut, Ulrike. (2009). English Corpus Linguistics, Volume 9: Non-native Speech: A Corpus-based Analysis of Phonological and Phonetic Properties of L2 English and German.

Jaffrey, Shahida. (1984). Sociolinguistic Survey of a Multilingual Community in Pakistan as Basis for Language Policy and Planning. UP System: PhD Thesis, March.

Jareta-Gonzales, Mildred. (1990). A Comparative Study of Formulaic Expressions in the Interlanguage (Filipino-English) of Filipino Bilinguals in Philippine and American Settings: The Influence of Social and Psychological Distance. UP Diliman: Thesis, March.

Jones, Angela and Jane McLachlan. (2009). GBR: Open University Press. Primary Languages in Practice: A Guide to Teaching and Learning.

Tankersley, Karen. (2003). Threads of Reading: Strategies for Literacy Development. USA: ASCD.
Kobayashi, Iori. (December 2008). "They Speak 'Incorrect English"”: Understanding Taiwanese Learners' Views on L2 Varieties of English in Philippine Linguistics Journal. The Linguistic Society of the Philippines, Vol. 39.

Kunschak, Claudia and Fang, Fan. (December 2008). "Intelligibility, Acceptability, Target-likeness: Teacher vs. Student Perspectives on the Teaching of Pronunciation within an EIL Framework" in Philippine Linguistics Journal. The Linguistic Society of the Philippines, Vol. 39, pp. 1-13.

Kerlinger, F. N. (1986). Foundations of Behavioral Research. New York: Holt, Rinehart, \& Winston.

Kreidler, Charles. (1997). Describing Spoken English: An Introduction. Routledge, London: Routledge.

Lagare, Conosesa.(1988). A Prototype Syllabus in English for Specific Purposes in the Vocational-Technical Schools (First Course in English for BSIE Students). UP System: M.A. Thesis.

Llamzon, Teodoro. (1970). A Handbook for Second Language Teaching. Philippines: Ateneo University Press.

Major, Roy C. (2008). 'Transfer in second language phonology" in (Eds.)Edwards Hansen, Jette and Zampini, Mary L.Phonology and Second Language Acquisition. Amsterdam: John Benjamins Publishing Co.

Mckenna, Sharon and Walpole, Micheal. (2007). Differentiated Reading Instruction: Strategies for the Primary Grades. USA: Guilford Press.

Ogden, Richard. (2009). Language and Linguistics: Introduction to English Phonetics. Edinburgh: Edinburgh University Press.

Peredo-Sarile, Angela. (1986). Determining the Comprehensibility and Acceptability of Phonological Varieties of Filipino-English as Used in Academic Lectures. UP System: PhDThesis.

Publication Manual of the American Psychological Association (( $8^{\text {th }}$ Reprint $)$. (1996). USA: American Psychological Association.

Ramirez, Arnulfo. (1985). Bilingualism Through Schooling Cultural Education for Minority and Majority Students. USA: New York Press.

Sevilla, Consuelo, Jesus Ochave, Twila Punzalan, Bella Regala, and Gabriel Uriarte. (1992). Research Method. Philippines: Rex Book Store.

Sheeler, W.D. and R. W. Markley. (1991). Sounds and Rhythm: A Pronunciation Course, $2^{\text {nd }}$ Edition. USA: Prentice-Hall, Inc.

Speak out! Newsletter of the IATEFL. Pronunciation Special Interest Group. No. 6, 12-16. England: IATEFL.

Strunk Jr., W. (2000). Elements of Style (Reprint of 1959 edition). USA: Allyn \& Bacon.

The Philippine Association for Language Teaching Philippines. Rosario Maminta in Focus: Selected Writings in Applied Linguistics. (2001). The Philippine Association for Language Teaching Philippines: Asian Graphics Printing, Inc.

Thompson, Roger M. (2003). Filipino English and Taglish, Language switching from multiple perspectives. USA: John Benjamins Publishing Company.

Verderber, Rudolf, Kathleen Verderber, and Deanna Sellnow. (2009). Effective Speaking: Challenges and Solutions. Philippines: MG Reprographics. 